\title{
Combined effects of calcium and dibutyryl cyclic AMP on germinal vesicle breakdown in the mouse oocyte
}

\author{
R. D. Powers and G. A. Paleos \\ Department of Biology, Boston College, Chestnut Hill, Massachusetts 02167, U.S.A.
}

\begin{abstract}
Summary. Mouse oocytes were cultured in the presence of dibutyryl cyclic AMP (dbcAMP) and various agents that affect cytoplasmic calcium concentrations. Treatments that inhibited calcium uptake potentiated the inhibitory effect of dbcAMP and treatments which stimulated cellular calcium uptake overcame the effect of dbcAMP. Elevated extracellular calcium (>10 mM) significantly decreased the inhibitory effect of concentrations of dbcAMP up to $150 \mu \mathrm{M}$ when compared to control levels of calcium $(1.7 \mathrm{mM})$. In addition, the calcium ionophore A23187 (>1 $\mu \mathrm{M})$ significantly overcame the effect of dbcAMP in media that contained 1.7 or 20 $\mathrm{mM}$ calcium. In the presence of $41 \mu \mathrm{M}$-dbcAMP the calcium antagonist verapamil increased (in a dose-dependent fashion) the percentage of oocytes blocked at the germinal vesicle stage, from $21 \%$ with $10 \mu \mathrm{M}$-verapamil to $99 \%$ with $200 \mu \mathrm{M}$. A similar dose-dependent, reversible potentiation of the effect of dbcAMP was found with tetracaine, which also lowers cytoplasmic calcium concentrations. These results suggest that a minimum level of cytoplasm calcium is required for the initiation of germinal vesicle breakdown and that the action of dbcAMP is mediated by its effect upon this calcium.
\end{abstract}

\section{Introduction}

In most mammalian oocytes, meiosis is arrested in the ovary at the diplotene stage of first prophase. Oocytes in mature follicles resume meiosis in response to a preovulatory surge of gonadotrophins; however, oocytes removed from the follicles with or without their surrounding cumulus cells resume meiosis spontaneously in the absence of gonadotrophic stimulation (rabbit: Pincus \& Enzmann, 1935; rodents: Edwards, 1962). Some isolated oocytes of the mouse, at least, can complete all aspects of maturation in vitro, as shown by the presence of 15-day-old living fetuses (Cross \& Brinster, 1970) and the birth of young (Mukherjee, 1972) after complete maturation and fertilization in vitro.

An increase in intracellular calcium has been shown to have a role in the re-initiation of meiosis in invertebrate and amphibian oocytes (Guerrier, Moreau \& Doree, 1978; Kostellow \& Morrill, 1980). In addition, it is well established that the level of intracellular calcium is critical to the regulation of somatic cell division (see review by Whitfield, Boynton, MacManus, Sikorska \& Tsang, 1979). However, we are aware of no report of a direct effect of calcium upon re-initiation of meiosis in a mammalian oocyte. Paleos \& Powers (1981) have shown that the spontaneous resumption of meiotic maturation by the isolated mouse oocyte is not affected by the concentration of external calcium in the absence of dibutyryl cyclic AMP (dbcAMP): germinal vesicle breakdown (GVB) was unaffected by the calcium ionophore A23187, the calcium 
antagonists verapamil or tetracaine, and calcium-depleted medium, although verapamil and tetracaine inhibited maturation at a stage between GVB and first polar body extrusion.

We have now examined the effect of the same substances on GVB in oocytes incubated in the presence of dbcAMP.

\section{Materials and Methods}

Swiss albino mice (CD-1) 6-8 weeks of age were obtained from Charles River Breeding Laboratories, Inc., Wilmington, Massachusetts. The mice were kept at a constant room temperature of $20^{\circ} \mathrm{C}$ and with controlled light (06:00-18:00 h). Oocytes were collected when the mice were $6-10$ weeks of age.

\section{Culture procedures}

Two $35 \times 10 \mathrm{~mm}$ dishes (Falcon Plastics) were each filled with $3.5 \mathrm{ml}$ of the medium for a particular treatment and equilibrated for $1 \mathrm{~h}$ at $37^{\circ} \mathrm{C}$ and $100 \%$ humidity in an appropriate atmosphere. Media containing a bicarbonate buffer were equilibrated in $5 \% \mathrm{CO}_{2}$ in air, and the media with a Hepes or Tris buffer were equilibrated in air.

The mice were killed by cervical dislocation, and the ovaries were removed aseptically and placed in one of the pair of dishes containing equilibrated medium. There were 4-6 ovaries per treatment, depending on the yield of oocytes per ovary at the time. Under a dissecting microscope, the oocytes were liberated by puncturing the follicles with a 30-gauge hypodermic needle. The time between collection of the ovaries and puncturing of the follicles was kept constant $(10 \mathrm{~min})$ and as short as possible to prevent the supplements from influencing the oocytes indirectly before they could be exposed directly in the culture medium. Oocytes possessing an intact germinal vesicle were harvested and transferred to the second dish containing equilibrated medium. Only the larger oocytes, 75-90 $\mu \mathrm{m}$ in diameter, were retained for culture. Oocytes with cumulus cells attached or with obvious signs of degeneration were discarded.

After culture for 22-23 h, the oocytes were examined with the aid of a dissecting microscope and classified as: (1) necrotic; (2) immature, (dictyate) oocytes with an intact germinal vesicle and nucleolus (GV); (3) oocytes showing GVB but no polar bodies (GVBD); or (4) mature oocytes with polar bodies (PB).

\section{Culture media}

The control medium used for culturing oocytes is a modification of the standard egg culture medium described by Biggers, Whitten \& Whittingham (1971). It contained: $87.9 \mathrm{mM}-\mathrm{NaCl}, 5.6$

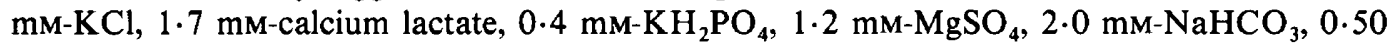
mM-sodium pyruvate, $21.4 \mathrm{~mm}$-sodium lactate, $5.6 \mathrm{~mm}$-glucose, $4.0 \mathrm{~g}$ crystalline bovine albumin 1 , and 20.0 mM-sodium Hepes. It was adjusted to $\mathrm{pH} 7.4$ with $\mathrm{HCl}$. This medium was designed with a low level of $\mathrm{NaHCO}_{3}$ so that the concentration of calcium could be raised above $1.71 \mathrm{mM}$ (by the addition of $\mathrm{CaCl}_{2}$ ) without precipitation. The reduction in $\mathrm{NaHCO}_{3}$ does not affect the rate or frequency of maturation (Paleos \& Powers, 1981).

Generally, media were prepared for each repetition of an experiment no earlier than 2 days in advance. Media containing dbcAMP, verapamil, or tetracaine were prepared no earlier than 1 day in advance. Stock solutions of A23187 (8 $\times 10^{-3} \mathrm{M}$ in dimethylsulphoxide $)$ were stored at $-20^{\circ} \mathrm{C}$. An aliquot of the stock was added to a completed medium immediately before incubation because the ionophore aggregates with time in a water solution. Also, exposure of the ionophore to light was kept to a minimum. For cultures involving the $\mathrm{Ca}$ ionophore, $0 \cdot 1 \%$ 
dimethylsulphoxide was also added to the control medium. The A23187 was purchased from Calbiochem-Behring Corporation (San Diego, California) and the verapamil was a generous gift from the Knoll Pharmaceutical Company (Cleveland, Ohio).

\section{Statistical analysis}

The effects of the treatments on the resumption of meiosis were statistically examined in a contingency table by comparing the number of oocytes retaining a germinal vesicle with those in which GVB occurred. Similarly, the effects of the treatments on the completion of meiotic maturation were examined in a contingency table by comparing the number of oocytes extruding polar bodies with those that remained at metaphase I. The amount of oocyte degeneration caused by various treatments was similarly evaluated by comparing the ratio of healthy looking oocytes to total oocytes cultured for the treatments with the ratio for controls in the same experiment. Overall $\chi^{2}$ values were calculated for the $2 \times 2$ and $2 \times r$ contingency tables.

\section{Results}

Except as indicated, $<5 \%$ of oocytes were classified as degenerate in any treatment.

\section{Experiment 1}

Oocytes were cultured in dbcAMP in elevated calcium concentrations or in the presence of the calcium ionophore A23187 to check whether an increase in free calcium in the cytoplasm can trigger the resumption of meiosis. The effects of 1.7 or $20 \mathrm{~mm}-\mathrm{Ca}^{2+}$ are given in Table 1 . There

Table 1. Effects of dbcAMP on meiosis in mouse oocytes (GV = germinal vesicle; GVB, germinal vesicle breakdown;

$\mathrm{PB}=$ polar bodies) in the presence of 1.7 or $20.0 \mathrm{~mm}$ calcium

\begin{tabular}{|c|c|c|c|c|c|c|}
\hline \multicolumn{3}{|c|}{ Treatment } & \multicolumn{4}{|c|}{ Oocytes } \\
\hline \multirow[b]{2}{*}{ No. } & \multirow[b]{2}{*}{$\begin{array}{l}\mathrm{Ca}^{2+} \\
(\mathrm{mM})\end{array}$} & \multirow[b]{2}{*}{$\begin{array}{c}\text { dbcAMP } \\
(\mathrm{mM})\end{array}$} & \multirow[b]{2}{*}{$\begin{array}{l}\text { Total } \\
\text { no. } \neq\end{array}$} & \multicolumn{3}{|c|}{ Stage of meiosis } \\
\hline & & & & GV $(\%) \S$ & GVB & PB (\%)ף \\
\hline $\begin{array}{c}\text { Control } \\
1\end{array}$ & $\begin{array}{r}1.7 \\
20.0\end{array}$ & $\begin{array}{l}0 \\
0\end{array}$ & $\begin{array}{l}190 \\
185\end{array}$ & $\begin{array}{l}0(0) \\
0(0)\end{array}$ & $\begin{array}{l}39 \\
14\end{array}$ & $\begin{array}{l}151(79) \\
171(92)^{\circ}\end{array}$ \\
\hline $\begin{array}{l}2 \\
3\end{array}$ & $\begin{array}{r}1.7 \\
20 \cdot 0\end{array}$ & $\begin{array}{l}0.061 \\
0.061\end{array}$ & $\begin{array}{l}194 \\
177\end{array}$ & $\begin{array}{r}12(6) \\
6(3)\end{array}$ & $\begin{array}{l}77 \\
23\end{array}$ & $\begin{array}{l}104(57) \\
148(87)^{\dagger}\end{array}$ \\
\hline $\begin{array}{l}4 \\
5\end{array}$ & $\begin{array}{r}1.7 \\
20.0\end{array}$ & $\begin{array}{l}0.092 \\
0.092\end{array}$ & $\begin{array}{l}184 \\
176\end{array}$ & $\begin{array}{l}57(31) \\
14(8) \dagger\end{array}$ & $\begin{array}{l}81 \\
41\end{array}$ & $\begin{array}{c}44(35) \\
121(75) \dagger\end{array}$ \\
\hline $\begin{array}{l}6 \\
7\end{array}$ & $\begin{array}{r}1.7 \\
20 \cdot 0\end{array}$ & $\begin{array}{l}0.12 \\
0.12\end{array}$ & $\begin{array}{l}179 \\
186\end{array}$ & $\begin{array}{c}110(62) \\
62(33) \dagger\end{array}$ & $\begin{array}{l}51 \\
54\end{array}$ & $\begin{array}{l}16(24) \\
70(56) \dagger\end{array}$ \\
\hline $\begin{array}{l}8 \\
9\end{array}$ & $\begin{array}{r}1.7 \\
20 \cdot 0\end{array}$ & $\begin{array}{l}0.15 \\
0.15\end{array}$ & $\begin{array}{l}181 \\
189\end{array}$ & $\begin{array}{l}148(82) \\
124(66)^{*}\end{array}$ & $\begin{array}{l}30 \\
20\end{array}$ & $\begin{array}{c}3(9) \\
43(68) \dagger\end{array}$ \\
\hline $\begin{array}{l}10 \\
11\end{array}$ & $\begin{array}{r}1.7 \\
20 \cdot 0\end{array}$ & $\begin{array}{l}0.20 \\
0.20\end{array}$ & $\begin{array}{l}211 \\
198\end{array}$ & $\begin{array}{l}193(91) \\
176(89)\end{array}$ & $\begin{array}{l}18 \\
12\end{array}$ & $\begin{array}{c}0(0) \\
10(45)^{*}\end{array}$ \\
\hline
\end{tabular}

Significantly different from treatment with matching dbcAMP concentration; ${ }^{*} P<0.01 ; \div P<0.001$.

$\ddagger$ Including any classified as degenerate. There were 5 replicates for each treatment.

$\S$ Of oocytes not degenerate.

१ Of oocytes undergoing GVB. 
was a dose-related inhibition of GVB by dbcAMP in medium containing 1.7 or 20 mM-calcium, but the percentage of oocytes that underwent GVB was generally greater in the treatments containing the higher dose of calcium. As the concentration of dbcAMP was increased from 0 to $0.12 \mathrm{mM}$, the difference between the percentages that underwent GVB for the two concentrations of calcium increased, and the difference diminished as the concentration of dbcAMP was increased from 0.12 to $0.20 \mathrm{~mm}$-dbcAMP. The completion of meiotic maturation was also influenced by external calcium; at all concentrations of dbcAMP tested, a significantly greater percentage of the oocytes which underwent GVB formed polar bodies in medium containing $20 \mathrm{~mm}$-calcium than in medium with $1.7 \mathrm{~mm}$-calcium.

\section{Experiment 2}

The possible effect of magnesium on the mouse oocyte was investigated (Table 2). There was a significant effect on GVB only at the highest $\mathrm{Mg}^{2+}$ concentration of $20.0 \mathrm{mM}$. The percentage of oocytes that extruded polar bodies was not significantly changed.

Table 2. Effect of magnesium on the inhibition of GVB in mouse oocytes by $0 \cdot 10 \mathrm{mM}$-dbcAMP

\begin{tabular}{|c|c|c|c|c|c|}
\hline \multicolumn{2}{|c|}{ Treatment } & \multicolumn{4}{|c|}{ Oocytes } \\
\hline \multirow[b]{2}{*}{ No. } & \multirow[b]{2}{*}{$\mathrm{Mg}^{2+}$} & \multirow[b]{2}{*}{$\begin{array}{l}\text { Total } \\
\text { no. } \dagger\end{array}$} & \multicolumn{3}{|c|}{ Stage of meiosis } \\
\hline & & & GV (\%) $\ddagger$ & GVB & PB $(\%) \S$ \\
\hline Control & $\begin{array}{r}1 \cdot 2 \\
20.0\end{array}$ & $\begin{array}{l}173 \\
180\end{array}$ & $\begin{array}{l}2(1) \\
1(1)\end{array}$ & $\begin{array}{l}23 \\
21\end{array}$ & $\begin{array}{l}147(86) \\
158(88)\end{array}$ \\
\hline 2 & 0.6 & 178 & $87(50)$ & 57 & $29(34)$ \\
\hline 3 & $1 \cdot 2$ & 171 & $85(53)$ & 44 & $32(42)$ \\
\hline 4 & $2 \cdot 5$ & 171 & $90(55)$ & 41 & $34(45)$ \\
\hline 5 & $5 \cdot 0$ & 169 & $79(48)$ & 49 & $37(43)$ \\
\hline 6 & $10 \cdot 0$ & 183 & $78(44)$ & 55 & $46(46)$ \\
\hline 7 & $20 \cdot 0$ & 169 & $55(33)^{*}$ & 62 & $51(45)$ \\
\hline
\end{tabular}

* Significantly different from Treatment 3 value; $P<0.001$.

$\dagger$ Including any classified as degenerate. There were 6 replicates/ treatment.

$\ddagger$ Of oocytes not degenerate.

$\S$ Of oocytes undergoing GVB.

\section{Experiment 3}

Oocytes were cultured for $22 \mathrm{~h}$ in $0.11 \mathrm{mM}$-dbcAMP plus the ionophore A23187 at concentrations up to $4.0 \times 10^{-3} \mathrm{mM}$. At concentrations of $\geq 1.0 \times 10^{-3} \mathrm{mM}$, the ionophore reduced the percentage of oocytes blocked at the germinal vesicle stage by dbcAMP (Table 3 ). In the presence and absence of dbcAMP, $4.0 \times 10^{-3} \mathrm{mM}$-ionophore decreased both the frequency of non-degenerate oocytes and the frequency of polar body formation.

\section{Experiment 4}

The effects of ionophore and elevated levels of calcium in various combinations were examined (Table 4). In the absence of the ionophore a dbcAMP concentration of $0.20 \mathrm{mM}$ and 
Table 3. Effects of ionophore A23187 on the inhibition of GVB in mouse oocytes by $0.10 \mathrm{mM}$-dbcAMP

\begin{tabular}{|c|c|c|c|c|c|}
\hline \multicolumn{2}{|c|}{ Treatment } & \multicolumn{4}{|c|}{ Oocytes } \\
\hline \multirow[b]{2}{*}{ No. } & \multirow[b]{2}{*}{$\begin{array}{c}\text { A23187 } \\
(\mathrm{mM})\end{array}$} & \multirow[b]{2}{*}{$\begin{array}{l}\text { Total } \\
\text { no.* }\end{array}$} & \multicolumn{3}{|c|}{ Stage of meiosis } \\
\hline & & & GV $(\%) \dagger$ & GVB & PB $(\%) \ddagger$ \\
\hline $\begin{array}{c}\text { Control } \\
1\end{array}$ & $\begin{array}{c}0 \\
4.0 \times 10^{-3}\end{array}$ & $\begin{array}{l}220 \\
220\end{array}$ & $\begin{array}{l}1(0) \\
1(1)\end{array}$ & $\begin{array}{l}18 \\
51\end{array}$ & $\begin{array}{l}201(91) \\
147(74)^{\mathrm{a}}\end{array}$ \\
\hline $\begin{array}{l}2 \\
3 \\
4 \\
5 \\
6 \\
7\end{array}$ & $\begin{array}{c}0 \\
6.0 \times 10^{-5} \\
2.5 \times 10^{-4} \\
1.0 \times 10^{-3} \\
2.0 \times 10^{-3} \\
4.0 \times 10^{-3}\end{array}$ & $\begin{array}{l}224 \\
231 \\
191 \\
213 \\
186 \\
233\end{array}$ & $\begin{array}{c}107(49) \\
107(47) \\
69(36) \\
48(23)^{\mathrm{c}} \\
37(21)^{\mathrm{c}} \\
51(25)^{\mathrm{c}}\end{array}$ & $\begin{array}{l}27 \\
28 \\
24 \\
58 \\
47 \\
57\end{array}$ & $\begin{array}{c}86(76) \\
91(76) \\
98(80) \\
101(64)^{b} \\
91(66)^{\mathrm{b}} \\
93(62)^{\mathrm{b}}\end{array}$ \\
\hline
\end{tabular}

a Significantly different from control value; $P<0.001$.

b Significantly different from Treatment 2 value; $P<0.01$.

' Significantly different from Treatment 2 value; $P<0.001$.

* Including any classified as degenerate. There were 5 replicates/ treatment.

$\dagger$ Of oocytes not degenerate.

$\ddagger$ Of oocytes undergoing GVB.

Table 4. Effects of ionophore A23187 or calcium on the inhibition of GVB in mouse oocytes by $0.2 \mathrm{mM}$-dbcAMP

\begin{tabular}{|c|c|c|c|c|c|c|}
\hline & \multicolumn{2}{|c|}{ Treatment } & \multicolumn{4}{|c|}{ Oocytes } \\
\hline \multirow[b]{2}{*}{ No. } & \multirow[b]{2}{*}{$\begin{array}{l}\mathrm{Ca}^{2+} \\
(\mathrm{mM})\end{array}$} & \multirow[b]{2}{*}{$\begin{array}{c}\mathrm{A} 23187 \\
(\mathrm{mM})\end{array}$} & \multirow[b]{2}{*}{$\begin{array}{l}\text { Total } \\
\text { no. } \neq\end{array}$} & \multicolumn{3}{|c|}{ Stage of meiosis } \\
\hline & & & & GV $(\%) \S$ & GVB & PB $(\%) 9$ \\
\hline Control & 1.7 & 0 & 245 & $1(0)$ & 49 & $195(80)$ \\
\hline 1 & 1.7 & 0 & 247 & $213(87)$ & 20 & $13(39)$ \\
\hline 2 & 1.7 & $2.5 \times 10^{-4}$ & 232 & $145(63)^{*+}+$ & 60 & $25(29)$ \\
\hline 3 & 1.7 & $2.0 \times 10^{-3}$ & 229 & $114(50)^{*}$ & 79 & $34(30)$ \\
\hline 4 & 20.0 & 0 & 217 & $176(81)$ & 22 & $19(46)$ \\
\hline 5 & $20 \cdot 0$ & $2.5 \times 10^{-4}$ & 220 & $107(52)$ & 60 & $39(39)$ \\
\hline
\end{tabular}

* Significantly different from Treatment 1 value, $P<0.001$.

+ Significantly different from values for Treatments 3 and $5, P<0.02$.

$\ddagger$ Including any degenerate oocytes. There were 6 replicates/treatment.

$\S$ Of oocytes not degenerate.

91 Of oocytes undergoing GVB.

increased $\mathrm{Ca}^{2+}$ levels of $20 \mathrm{~mm}$ had no stimulatory effect upon GVB (see also Table 1). However, the presence of ionophore did have an effect on germinal vesicle breakdown and some potentiation of the effects of the ionophore with high calcium in the external medium seems likely.

\section{Experiment 5}

Oocytes were cultured with several different concentrations of verapamil, which has been suggested to block $\mathrm{Ca}^{2+}$ channels in the cell surface (Fleckenstein, 1977), plus a low 
concentration of dbcAMP (Table 5). There was a dose-dependent effect of verapamil on GVB, and at high concentrations verapamil blocked GVB and polar body formation (Table 5). When the oocytes in some of the treatment groups were cultured for an additional $20 \mathrm{~h}$ in medium lacking verapamil but still containing dbcAMP, almost all of the oocytes which were in $0 \cdot 10$ mM-verapamil plus $0.041 \mathrm{mM}$-dbcAMP for the first $22 \mathrm{~h}$ underwent GVB (Table 5) but only $11 \%$ of the oocytes which underwent GVB continued to form polar bodies, Only $59 \%$ of the oocytes blocked at the germinal vesicle stage by $0.20 \mathrm{mM}$-verapamil plus $0.041 \mathrm{mM}$-bdcAMP underwent GVB when transferred to medium with the dbcAMP alone.

Table 5. Effects of verapamil and $0.041 \mathrm{~mm}$-dbcAMP on meiotic maturation of mouse oocytes

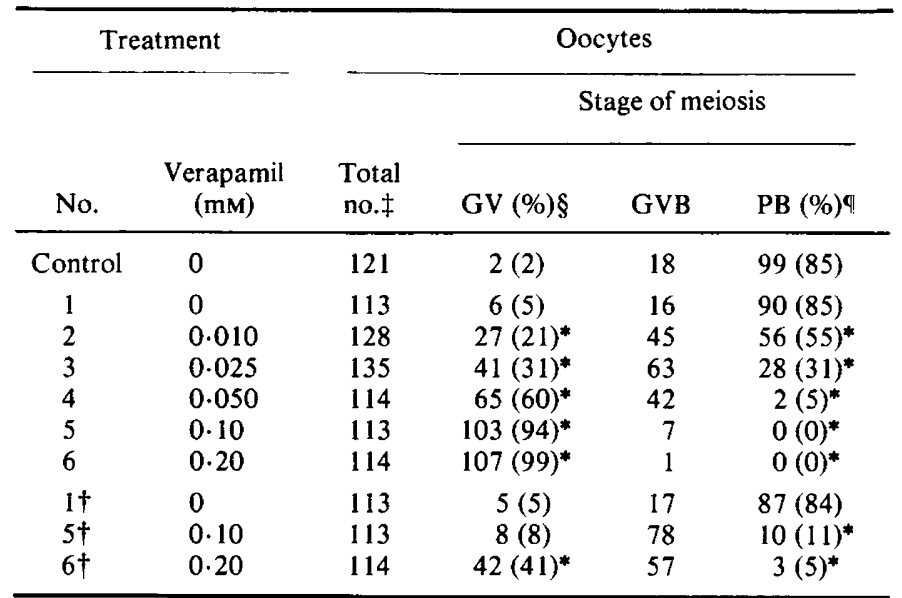

* Significantly different from Treatment 1 value, $P<0.001$.

+ Oocytes in these tests were incubated for a further $20 \mathrm{~h}$ in the absence of verapamil.

$\ddagger$ Including any degenerate oocytes. There were 6 replicates/ treatment.

$\S$ Of oocytes not degenerate.

q) Of oocytes undergoing GVB.

\section{Experiment 6}

Tetracaine, which is also known to be a calcium antagonist (Rahwan, Piascik \& Witiak, 1979), was used in an experiment similar to Exp. 5. With 0.041 mM-dbcAMP in the medium, tetracaine caused a dose-related inhibition of GVB (Table 6). The majority (82\%) of the oocytes which were in $0.40 \mathrm{~mm}$-tetracaine $+0.041 \mathrm{mM}$-dbcAMP for the first $22 \mathrm{~h}$ of culture underwent GVB when cultured in medium with the dbcAMP alone, indicating that the effect on GVB of the highest concentration of tetracaine is largely reversible. However, of the oocytes that underwent GVB, far fewer formed polar bodies than did oocytes cultured in $0.041 \mathrm{mM}$-dbcAMP alone. These results, and the similar effect of verapamil in Exp. 5 could reflect some residual effects of the treatments. It is also possible that the length of time that the oocytes were maintained in culture at the germinal vesicle stage caused irreversible changes in some of the oocytes which prevented maturation.

\section{Discussion}

The results presented in Table 1 demonstrate that elevated levels of extracellular calcium can overcome the block to GVB caused by dbcAMP in the mouse oocyte in vitro. At low levels of 
Table 6. The effects of tetracaine and $0.041 \mathrm{~mm}$-dbcAMP on meiotic maturation of mouse oocytes

\begin{tabular}{|c|c|c|c|c|c|}
\hline \multicolumn{2}{|c|}{ Treatment } & \multicolumn{4}{|c|}{ Oocytes } \\
\hline \multirow[b]{2}{*}{ No. } & \multirow[b]{2}{*}{$\begin{array}{l}\text { Tetracaine } \\
\text { (mM) }\end{array}$} & \multirow[b]{2}{*}{$\begin{array}{l}\text { Total } \\
\text { no. } \neq\end{array}$} & \multicolumn{3}{|c|}{ Stage of meiosis } \\
\hline & & & GV $(\%) \S$ & GVB & PB (\%) \\
\hline Control & 0 & 180 & $0(0)$ & 24 & $153(86)$ \\
\hline $\begin{array}{l}1 \\
2 \\
3 \\
4 \\
5\end{array}$ & $\begin{array}{l}0 \\
0 \cdot 10 \\
0 \cdot 20 \\
0.30 \\
0.40\end{array}$ & $\begin{array}{l}171 \\
162 \\
160 \\
161 \\
155\end{array}$ & $\begin{array}{c}8(5) \\
12(8) \\
44(31)^{\mathrm{b}} \\
78(53)^{\mathrm{b}} \\
117(83)^{\mathrm{b}}\end{array}$ & $\begin{array}{r}32 \\
122 \\
96 \\
69 \\
24\end{array}$ & $\begin{array}{c}126(80) \\
22(15)^{*} \\
2(2)^{*} \\
0(0)^{*} \\
0(0)^{*}\end{array}$ \\
\hline $\begin{array}{l}1 \dagger \\
5 \dagger\end{array}$ & $\begin{array}{l}0 \\
0.40\end{array}$ & $\begin{array}{l}171 \\
155^{\mathrm{a}}\end{array}$ & $\begin{array}{c}4(2) \\
22(18)^{b}\end{array}$ & $\begin{array}{l}35 \\
71\end{array}$ & $\begin{array}{c}123(78) \\
26(27)^{*}\end{array}$ \\
\hline \multicolumn{6}{|c|}{$\begin{array}{l}\text { * Significantly different from Treatment } 1 \text { value, } P<0.001 \text {. } \\
\text { † Oocytes in these tests were incubated for a further } 20 \mathrm{~h} \text { in the } \\
\text { sence of tetracaine. } \\
\text { † Including any degenerate oocytes; there were } 5 \text { replicates/ } \\
\text { atment. }\end{array}$} \\
\hline
\end{tabular}

dbcAMP, few oocytes are arrested at the germinal vesicle stage, and the effect of elevated calcium is not statistically significant, while at high levels of dbcAMP $(0.2 \mathrm{mM})$ most of the oocytes are arrested and elevated calcium has no effect. The ability of calcium to overcome the germinal vesicle arrest caused by dbcAMP suggests that they share a common mechanism for the regulation of GVB. In addition to stimulating GVB, elevated calcium also increases the percentage of oocytes which proceed to the polar body stage after GVB. Increased concentrations of dbcAMP decrease the percentage of oocytes with GVB which proceed to the polar body stage. We conclude that calcium and dbcAMP can interact at two different stages to regulate meiotic maturation. The stimulation of GVB shown in Table 2 for magnesium suggests that this conclusion might be generally applicable to divalent cations. However, experiments similar to those in Exp. 2 have been performed with calcium (data not shown) and they demonstrate a greater stimulatory effect at lower calcium concentrations (10 compared with 20 $\mathrm{mM}$ ) and the effect is probably, therefore, more selective for the calcium ion.

The divalent cation ionophore A23187 has been a valuable tool for studying calcium functions in many biological systems. By mediating the entry of calcium into cells, this ionophore is capable of activating many calcium-controlled processes such as exocytosis, uncoupling of cell communication, cell division after fertilization, and the acrosome reaction (Rose \& Loewenstein, 1975; Foreman, Garland \& Mongar, 1976; Epel, 1977; Collins \& Epel, 1977). The ionophore was able to stimulate GVB in oocytes exposed to dbcAMP at a concentration $(0.10 \mathrm{mM})$ that is within the range in which the oocytes are sensitive to elevated extracellular calcium (Table 1). However, the ionophore at $4.0 \times 10^{-3} \mathrm{mM}$ had an inhibitory effect upon polar body formation in the presence or absence of dbcAMP. Since this conflicts with the results above and in our previous study on the effects of calcium alone (Paleos \& Powers, 1981), we believe that this inhibitory effect may be related to the fact that the oocytes in Table 3 seem to be less sensitive to the effects of dbcAMP upon polar body formation.

If the effect of the ionophore upon GVB is related to calcium uptake by the oocytes, then elevated calcium levels in the culture medium should increase the response. The effect of $2.5 \times 10^{-4} \mathrm{~mm}-\mathrm{A} 23187$ was potentiated in high calcium and the effect of high calcium was 
potentiated by the addition of ionophore (Table 4), strongly suggesting that both treatments were acting together to raise cytoplasmic calcium levels.

Paleos \& Powers (1981) showed that treatments which can block calcium uptake (i.e. verapamil or tetracaine) do not block spontaneous GVB in mouse oocytes in the absence of dbcAMP. The present study demonstrated that calcium can trigger GVB in the presence of dbcAMP. We conclude from these two results that a specific level of cytoplasmic calcium is required for GVB but that the source of this calcium need not be extracellular unless dbcAMP is present. However, extracellular calcium has an important effect on the viability of immature oocytes. Calcium-free medium causes immature oocytes to become necrotic after a short time in culture (Paleos \& Powers, 1981). This toxic effect may be related to the disruption of gap junctions on the surface of the oocyte when it is removed from the follicle. Rose \& Loewenstein (1975) have shown that highly permeable intercellular gap junctions have their permeability rapidly decreased when they are contacted by calcium. It is possible that the gap junctions on the surface of the oocyte (Anderson \& Albertini, 1976) remain highly permeable in calcium-free medium and a subsequent alteration of cell contents proves toxic. This effect would not be related to the normal regulation of meiotic events.

The experiments suggest that cytoplasmic calcium has a central regulatory role in GVB of the mouse oocyte in vitro. While intracellular reservoirs of calcium are apparently sufficient to supply calcium for GVB in vitro without dbcAMP, exogenous calcium is required to stimulate GVB in the presence of dbcAMP. This suggests that dbcAMP may act by reducing cytoplasmic calcium, perhaps by stimulation of a membrane-bound calcium pump, as found in other systems (Berridge, 1975). We believe that further investigations of calcium localization and movement in the mouse oocyte will be of value in elucidating the processes that stimulate GVB in vitro and in vivo.

\section{References}

Anderson, E. \& Albertini, D.F. (1976) Gap junctions between the oocyte and companion follicle cells in the mammalian ovary. J. Cell Biol. 71, 680-686.

Berridge, M.J. (1975) The interaction of cyclic nucleotides and calcium in the control of cellular activity. Adv. Cyclic Nucleotide Res. 6, 1-98.

Biggers, J.D., Whitten, W.K. \& Whittingham, D.G. (1971) The culture of mouse embryos in vitro. In Methods in Mammalian Embryology, pp. 86-116. Ed. J. C. Daniel. E. H. Freeman, San Francisco.

Collins, F. \& Epel, D. (1977) The role of calcium ions in the acrosome reaction of sea urchin sperm. Expl Cell Res. 106, 211-222.

Cross, P.C. \& Brinster, R.L. (1970) In vitro development of mouse oocytes. Biol. Reprod. 3, 298-307.

Edwards, R.G. (1962) Meiosis in ovarian oocytes of adult mammals. Nature, Lond. 196, 446-450.

Epel, D. (1977) The egg surface in relation to metabolic activation at fertilization. In Immunobiology of Gametes, pp. 235-254. Eds M. Edidin \& M. H. Johnson. Cambridge University Press.

Fleckenstein, A. (1977) Specific pharmacology of calcium in myocardium, cardiac pacemakers, and vascular smooth muscle. Ann. Rev. Pharmacol. Toxicol. 17, 149-166.

Foreman, J.C., Garland, L.G. \& Mongar, J.L. (1976) The role of calcium in secretory processes: model studies in mast cells. In Calcium in Biological Systems, pp. 193-218. Ed. C.J. Duncan. Cambridge University Press.
Guerrier, P., Moreau, M. \& Doree, M. (1978) Control of meiosis reinitiation in starfish: calcium ion as the primary effective trigger. Annls Biol. Anim. Biochim. Biophys. 18, 441-452.

Kostellow, A.B. \& Morrill, G.A. (1980) Calcium dependence of steroid and guanine $3^{\prime}, 5^{\prime}$-monophosphate induction of germinal vesicle breakdown in Rana pipiens oocytes. Endocrinology 106, 10121019.

Mukherjee, A.B. (1972) Normal progeny from fertilization in vitro of mouse oocytes matured in culture and spermatozoa capacitated in vitro. Nature, Lond. 327, 397-398.

Paleos, G.A. \& Powers, R.D. (1981) The effect of calcium on the first meiotic division of the mammalian oocyte. J. exp. Zool. 217, 409-416.

Pincus, G. \& Enzmann, E.V. (1935) The comparative behavior of mammalian eggs in vivo and in vitro. 1. The activation of ovarian eggs. J. exp. Med. 62, 665-675.

Rahwan, R.G., Piascik, M.F. \& Witiak, P.T. (1979) The role of calcium antagonism in the therapeutic action of drugs. Can. J. Pharmacol. 58, 443-460.

Rose, B. \& Loewenstein, W.R. (1975) Permeability of cell junctions depends upon local cytoplasmic calcium activity. Nature, Lond. 254, 250-252.

Whitfield, J.F., Boynton, A.L., MacManus, J.P., Sikorska, M. \& Tsang, B.K. (1979) The regulation of cell proliferation by calcium and cyclic AMP. Molec. cell. Biochem. 27, 155-179. 